\title{
Comparative study of functional benefits and dispensarization of three treatment alternatives in the total edentation
}

\author{
Studiu comparativ asupra beneficiilor funcţionale şi dispensarizării a \\ trei alternative de tratament în edentaţia totală
}
Marina Meleşcanu-Imre, Elena Preoteasa, Paula Perlea, Paul Bores, Mihaela Pantea, Ana Maria Țâncu
Facultatea de Medicină Dentară, Universitatea de Medicină şi Farmacie „Carol Davila“, Bucureşti, România

\begin{abstract}
Complete edentulism status represents for the patient a moment with important functional and emotional meanings associated with aging and frequently with a complex general pathology. The rehabilitation of the full edentulous patient represents a real challenge for the dentist through its complexity. Therefore, we are highlighting the importance of knowing alternatives of treatment outside the conventional complete denture. The study analyzes three of the main methods of prosthesis in the full and subtotal edentulism (conventional complete denture, overdenture on natural teeth and on mini implants) in terms of patient satisfaction with the rehabilitation of the functionality of the oral system as well as the long-term outcome of prosthesis. Overdenture shows up to be a successful alternative in rehabilitation of the oro-maxilo-facial system, with benefits on the quality of life and a high degree of patient satisfaction.
\end{abstract}

Keywords: full edentulism, overdenture, patient satisfaction

\section{REZUMAT}

Instalarea edentaţiei totale reprezintă pentru pacient un moment cu importante consecinţe funcţionale, dar şi semnificaţii emoţionale asociate cu îmbătrânirea şi frecvent cu o patologie generală complexă. Reabilitarea edentatului total reprezintă pentru medicul stomatolog o adevărată provocare prin complexitatea acesteia. De aceea, se evidenţiază importanţa cunoaşterii alternativelor de tratament în afara protezării totale convenţionale. Studiul analizează comparativ trei dintre principale metode de protezare ale edentației totale şi subtotale (protezarea totală convenţională, supraprotezarea pe dinţi naturali şi cea pe miniimplanturi) din perspectiva gradului de satisfacţie al pacientului cu privire la reabilitarea funcţionalităţii ADM (aparat dento maxilar), precum şi a rezultatului pe termen lung al protezării, supraprotezarea dovedindu-se o alternativă de succes în reabilitarea funcţionalităţii, cu beneficii asupra calităţii vieţii şi cu un grad crescut de satisfacţie pentru pacient.

Cuvinte cheie: edentaţie totală, supraprotezare, grad de satisfacţie

\section{INTRODUCERE}

Protezarea edentaţiei totale reprezintă o solicitare terapeutică în creştere, având în vedere creşterea vârstei medii de viaţă şi, respectiv, a numărului de persoane în vârstă. Cele mai recente raportări OMS prevăd pentru perioada 2000-2030 o creştere a nu- mărului persoanelor în vârstă, mai evidentă în țările dezvoltate. Astfel, în Statele Unite ale Americii, numărul persoanelor de peste 55 de ani va crește de la 59 la 108 milioane, în Japonia - de la 38 la 51 milioane, în Marea Britanie - de la 15,5 la 23 milioane, în Rusia - de la 33 la 44 milioane, iar în China - de la 175 la 456 milioane. 
Edentația totală este o stare patologică cronică din cauza evoluției sale progresive (1). O mare parte dintre persoanele edentate protezate convențional sunt în general satisfăcute, însă un procent de aproximativ $30 \%$ dintre pacienți acuză nemulțumiri (2). Principalele problemele care apar sunt menținerea şi stabilitatea deficitară a protezei şi durerea în timpul masticației, în special în legătură cu proteza mandibulară. $\mathrm{Cu}$ timpul, intensitatea durererii creşte şi dificultatea din timpul exercitării funcțiilor orale periclitează alimentația şi abilitatea de a comunica cu uşurinţă şi încredere. Diminuarea atractivităţii aspectului facial atrage mari probleme psihosociale, dificultăți în comunicare şi evitarea colectivităţilor, precum şi izolarea (3).

Motivația acestui studiu a pornit de la neajunsurile protezării totale convenționale, legate în special de dificultățile în asigurarea stabilității protezelor şi restabilirea funcționalităţii ADM.

Obiectivul acestui studiu este de a cuantifica nivelul de satisfacție al pacienților în funcție de diferitele soluții de tratament disponibile pentru a fundamenta decizia medicului privind alegerea abordării pentru optimizarea rezultatului protetic. Astfel, în contextul creşterii importanţei evaluării atente şi complete a pacientului, unul dintre criteriile esențiale este chiar nivelul aşteptărilor pacientului. Comunicarea foarte bună între clinician şi pacient este o precondiție pentru un tratament de succes. Aceasta permite pacientului să obțină informații cu privire la costul tratamentului, la beneficiile, dar şi la riscurile lui, iar medicilor le permite să identifice alternativa optimă de tratament.

$\mathrm{O}$ data cu introducerea implantelor în practica stomatologică, supraprotezarea mandibulară pe 2 implante s-a impus ca alternativă de tratament standard în edentaţia totală (4).

Trecerea de la stadiul de dentat la cel de edentat presupune faza de edentație subtotală. Soluțiile pentru îmbunătățirea retenției protezelor totale supraprotezarea pe dinți naturali - datează încă din 1856, când Ledger a propus utilizarea dinților naturali pentru ancorarea protezelor mobilizabile. Acest tip de soluție primeşte însă un impuls decisiv în 1958, când Rehm, Brill şi Miller reintroduc şi promovează îmbunătăţirea eficienței şi funcționalităţii reabilitării protetice cu ajutorul protezelor totale ancorate pe dinți naturali restanţi. În 1969, Morrow si colab. au sugerat păstrarea a doar câțiva milime- tri din dinţii naturali ce urmează a fi suport pentru proteza totală şi au elaborat un plan cu etapele realizării supraprotezelor. Începând cu anii 70, în stomatologie s-a acordat o importanță crescută prezervării ultimilor dinţi restanţi din dentiţiile compromise (5).

De-a lungul anilor, designul protezelor totale a suferit numeroase modificări pentru a îmbunătăți suportul şi stabilitatea. Mericske-Stern şi colab. au testat eficiența acestor supraprotezări ca o alternativă la protezele convenționale. Păstrarea rădăcinilor dentare conservă creasta alveolară, furnizează feedback senzorial şi îmbunătățesc considerabil stabilitatea protezelor $(6,7)$.

În acest context, a fost introdusă o nouă alternativă în protezarea edentaţiei totale: supraprotezarea pe miniimplanturi. Utilizarea miniimplanturilor este o modalitate nouă de tratament şi o alternativă a tratamentului cu implanturi convenționale $(8,9,10)$.

Utilizarea miniimplanturilor în tratamentul edentației totale a devenit din ce în ce mai populară pentru pacienții cu dificultăţi în adaptarea cu protezele totale convenționale. Chiar dacă substratul biologic al implanturilor introduse în os diferă de cel al rădăcinilor dentare înconjurate de sistemul parodontal, conceptul protetic este similar. Bineînțeles că sensibilitatea proprioceptivă în cazul implanturilor este redusă din cauza absenței receptorilor parodontali, însă funcțiile orale sunt comparabile cu cele din supraprotezarea pe dinţi naturali, deoarece nu depind de prezența parodonțiului. Avantajele folosirii miniimplanturilor constau în diminuarea considerabilă a resorbției crestelor edentate, în menţinerea eficienței masticatorii şi în beneficii psihologice (11). Majoritatea lucrărilor de specialitate au demonstrat o rată crescută de succes atunci când protezarea totală se realizează cu ajutorul miniimplanturilor (12).

Supraprotezarea pe miniimplanturi prezintă următoarele avantaje principale: posibilitatea adaptării protezelor convenționale vechi la miniimplanturile inserate, posibilitatea încărcării imediate a miniimplanturilor - procedură considerată minimum invazivă (stres operator redus pentru pacient) - şi rata de succes pe o durată de cel puțin 5 ani (13).

\section{MATERIAL ŞI METODĂ}

Acest studiu urmăreşte analiza comparativă a trei alternative de tratament: protezare convențio- 
nală, supraprotezare pe dinţi naturali şi supraprotezare pe miniimplanturi, în privința restabilirii funcționale, a igienizării şi a dispensarizării.

Pentru realizarea acestui studiu comparativ, am consultat literatura de specialitate şi am formulat un chestionar care reflectă cele mai importante aspecte care îi preocupă pe pacienții purtători de proteze dentare. Au fost selecționați 75 de pacienți tratați în cadrul Disciplinei de Protezare Totală UMF „Carol Davila“ din Bucureşti, cu vârste cuprinse între 50 şi 82 de ani, 39 de sex masculin şi 36 de sex feminin. Vechimea protezărilor variază între 1 şi 10 ani, perioadă de timp suficient de lungă pentru a fi apreciate cu acuratețe aspecte precum funcția masticatorie, aplicarea şi îndepărtarea protezei, igiena orală, fonetica şi estetica.

Eşantionul luat în calcul a fost constituit cu respectarea următoarelor criterii: lipsa semnelor sau simptomelor tulburării articulației temporo-mandibulare, lipsa afecțiunilor sistemice ce ar afecta muşchii, ligamentele sau oasele, relație intermaxilară clasa I după clasificarea Angle.

În privința tipului de protezare, au fost incluşi în studiu 27 de pacienți reabilitaţi prin protezare convenționala, 25 prin supraprotezare pe dinți şi 23 prin supraprotezare pe miniimplanturi. Au fost excluşi cei care prezentau fenomene de involuție cu dificultăţi de comunicare, condiții absolut necesare în vederea culegerii datelor şi, de asemenea, cei la care s-au remediat aspectele percepute ca nesatisfăcătoare prin intervenții la nivelul protezelor vechi. Structura pacienților din eşantion este sintetizată în tabelul de mai jos:

TABELUL 1. Distribuția persoanelor din eşantion, pe categorii

\begin{tabular}{|l|c|c|c|c|c|}
\hline \multirow{2}{*}{ Târstă/sex } & \multicolumn{2}{|c|}{$50-65$ ani } & \multicolumn{2}{|c|}{$65+$ ani } & \multirow{2}{*}{ Total } \\
\cline { 2 - 6 } & $\mathrm{m}$ & $\mathrm{f}$ & $\mathrm{m}$ & $\mathrm{f}$ & \\
\hline 1. Convențională & 6 & 5 & 9 & 7 & 27 \\
\hline $\begin{array}{l}\text { 2. Supraprotezare pe } \\
\text { dinți }\end{array}$ & 6 & 6 & 6 & 7 & 25 \\
\hline $\begin{array}{l}\text { 3. Supraprotezare pe } \\
\text { miniimplanturi }\end{array}$ & 7 & 6 & 5 & 5 & 23 \\
\hline Total & 19 & 17 & 20 & 19 & 75 \\
\hline
\end{tabular}

Chestionarul a cuprins 6 întrebări, fiind identificate aspectele considerate cele mai relevante legate de tulburări funcționale, aspecte practice (inserția şi dezinserția protezei, igienizarea), pecum şi dis- pensarizarea. Chestionarul este de tip închis, cu răspunsuri unice. A fost propus pacienților cu minimum un an vechime de la protezare.

TABELUL 2. Formularul de chestionar distribuit

eşantionului

\begin{tabular}{|c|c|c|c|c|c|}
\hline & $\begin{array}{l}\text { Nesatis- } \\
\text { făcător }\end{array}$ & Neutru & $\begin{array}{l}\text { Mo- } \\
\text { derat }\end{array}$ & Bine & Excelent \\
\hline $\begin{array}{l}\text { 1. Cum apreciaţi } \\
\text { este ca } \\
\text { zâmbetului } \\
\text { dumneavoastră? }\end{array}$ & & & & & \\
\hline $\begin{array}{l}\text { 2. Care este } \\
\text { calitatea actului } \\
\text { mas cator? }\end{array}$ & & & & & \\
\hline $\begin{array}{l}\text { 3. Cum apreciaţi } \\
\text { calitatea } \\
\text { exprimării } \\
\text { și a vorbirii } \\
\text { dumneavoastră ? }\end{array}$ & & & & & \\
\hline $\begin{array}{l}\text { 4. Cum evaluaţi } \\
\text { ușurinţa } \\
\text { igienizării } \\
\text { protezei? }\end{array}$ & & & & & \\
\hline $\begin{array}{l}\text { 5. Cum evaluaţi } \\
\text { ușurinţa aplicării } \\
\text { și dezinserţiei } \\
\text { protezelor? }\end{array}$ & & & & & \\
\hline $\begin{array}{l}\text { 6. În ul mul } \\
\text { an, de câte ori } \\
\text { aţi avut nevoie } \\
\text { de un control } \\
\text { pentru disconfort, } \\
\text { fractura } \\
\text { protezei sau alte } \\
\text { probleme? }\end{array}$ & $\begin{array}{l}4 \text { sau } \\
\text { mai } \\
\text { multe } \\
\text { ori }\end{array}$ & 3 ori & 2 ori & $\begin{array}{c}1 \\
\text { dată }\end{array}$ & Niciodată \\
\hline
\end{tabular}

Variabilele principale sunt estetica, masticația, fonația, igienizarea, aplicarea şi dezinserția protezelor, frecvența vizitelor la medic pentru probleme legate de tratamentul protetic. Am constatat că acestea sunt de maxim interes atât pentru satisfacția pacientului, cât şi pentru succesul tratamentului medical. De asemenea, s-au luat in consideraţie şi alte variabile, cum ar fi: vârsta, sexul, durata protezării. Trebuie menţionat că datele culese sunt cu caracter anonim, rezultatele obținute fiind utilizate în scop academic, non-comercial, iar pentru culegerea lor s-a cerut consimțământul informat al pacienților.

Cei 75 de pacienţi participanți la studiu au fost împărțiţi în 3 categorii, în funcție de tipul de protezare, astfel: 27 de pacienți reabilitați prin protezare convențională, 25 prin supraprotezare pe dinți şi 23 prin supraprotezare pe miniimplanturi. 
TABELUL 3. Centralizator răspunsuri pacienți categorie A - pacienți cu proteze convenționale

\begin{tabular}{|l|c|c|c|c|c|}
\hline & $\begin{array}{c}\text { Nesatis- } \\
\text { făcător }\end{array}$ & Neutru & Moderat & Bine & Excelent \\
\hline Întrebare 1 & 0 & 2 & 9 & 10 & 6 \\
\hline Întrebare 2 & 2 & 5 & 10 & 6 & 4 \\
\hline Întrebare 3 & 3 & 8 & 9 & 5 & 2 \\
\hline Întrebare 4 & 0 & 2 & 7 & 10 & 8 \\
\hline Întrebare 5 & 0 & 1 & 9 & 12 & 5 \\
\hline Întrebare 6 & $\begin{array}{c}4 \text { sau mai } \\
\text { multe ori }\end{array}$ & 3 ori & 2 ori & o dată & niciodată \\
\hline & 0 & 0 & 1 & 3 & 23 \\
\hline
\end{tabular}

TABELUL 4. Centralizator răspunsuri pacienți categorie $B$ - pacienți cu proteze sprijinite pe dinți

\begin{tabular}{|l|c|c|c|c|c|}
\hline & $\begin{array}{c}\text { Nesatis- } \\
\text { făcător }\end{array}$ & Neutru & Moderat & Bine & Excelent \\
\hline Intrebare 1 & 0 & 0 & 2 & 13 & 10 \\
\hline Intrebare 2 & 0 & 0 & 4 & 14 & 7 \\
\hline Intrebare 3 & 0 & 0 & 11 & 8 & 6 \\
\hline Intrebare 4 & 0 & 1 & 8 & 10 & 6 \\
\hline Întrebare 5 & 0 & 1 & 7 & 9 & 6 \\
\hline Întrebare 6 & $\begin{array}{c}4 \text { sau mai } \\
\text { multe ori }\end{array}$ & 3 ori & 2 ori & $\begin{array}{c}\text { o } \\
\text { dată }\end{array}$ & niciodată \\
\hline & 0 & 0 & 1 & 4 & 20 \\
\hline
\end{tabular}

TABELUL 5. Centralizator răspunsuri pacienți categorie C - pacienți cu proteze sprijinite pe miniimplanturi

\begin{tabular}{|l|c|c|c|c|c|}
\hline & $\begin{array}{c}\text { Nesatis- } \\
\text { făcător }\end{array}$ & Neutru & Moderat & Bine & Excelent \\
\hline Întrebare 1 & 0 & 0 & 3 & 12 & 8 \\
\hline Întrebare 2 & 0 & 0 & 4 & 11 & 8 \\
\hline Întrebare 3 & 0 & 0 & 6 & 9 & 8 \\
\hline Întrebare 4 & 0 & 1 & 7 & 9 & 6 \\
\hline Întrebare 5 & 0 & 0 & 1 & 12 & 10 \\
\hline Întrebare 6 & $\begin{array}{c}4 \text { sau } \\
\text { mai } \\
\text { multe } \\
\text { ori }\end{array}$ & 3 ori & 2 ori & o dată & niciodată \\
\hline & 0 & 0 & 0 & 3 & 22 \\
\hline
\end{tabular}

\section{REZULTATE ŞI DISCUŢII}

În urma centralizării şi prelucrării datelor obținute, am creat o serie de grafice statistice pentru fiecare întrebare separat. Conform tabelelor centralizatoare de mai sus, fiecărei categorii de pacienți îi revine o literă şi fiecărui răspuns o cifră, astfel:

A - pacienți cu proteze convenționale

B - pacienți cu supraproteze sprijinite pe dinți

C - pacienți cu supraproteze sprijinite pe miniimplanturi

1- nesatisfăcător

2 - neutru

3 - moderat

4 - bine

5 - excelent

Pentru analiza nivelului de satisfacție, studiul urmăreşte şi criteriile de vârstă şi sex. Astfel, eşantionul a fost împărțit în următoarele subcategorii: bărbați între 50 şi 65 ani, bărbaţi peste 65 ani, femei între 50 şi 65 ani, precum şi femei peste 65 ani. Pentru fiecare categorie şi la fiecare întrebare, s-a calculat un scor în funcție de nomenclatorul descris mai sus, care semnifică nivelul mediu de satisfacție al categoriei respective. Formula de calcul a scorului este media ponderată a notelor acordate de pacienți.

\section{Scor $-\sum \frac{\text { nota } k * n r \text {. pacienți care au acordat } k}{\text { număr total de pacienți din categorie }}$}

Conform graficului primei întrebări (Fig. 1), se observă un grad uşor crescut de satisfacție privind estetica la pacienții cu supraprotezări față de pacienții protezați convențional. Majoritatea celor $\mathrm{cu}$ proteze convenționale au apreciat estetica restaurării cu moderat sau bine, în timp ce pacienții cu su-

\section{GRADUL DE SATISFACTIE PRIVIND ESTETICA ZÂMBETULUI}

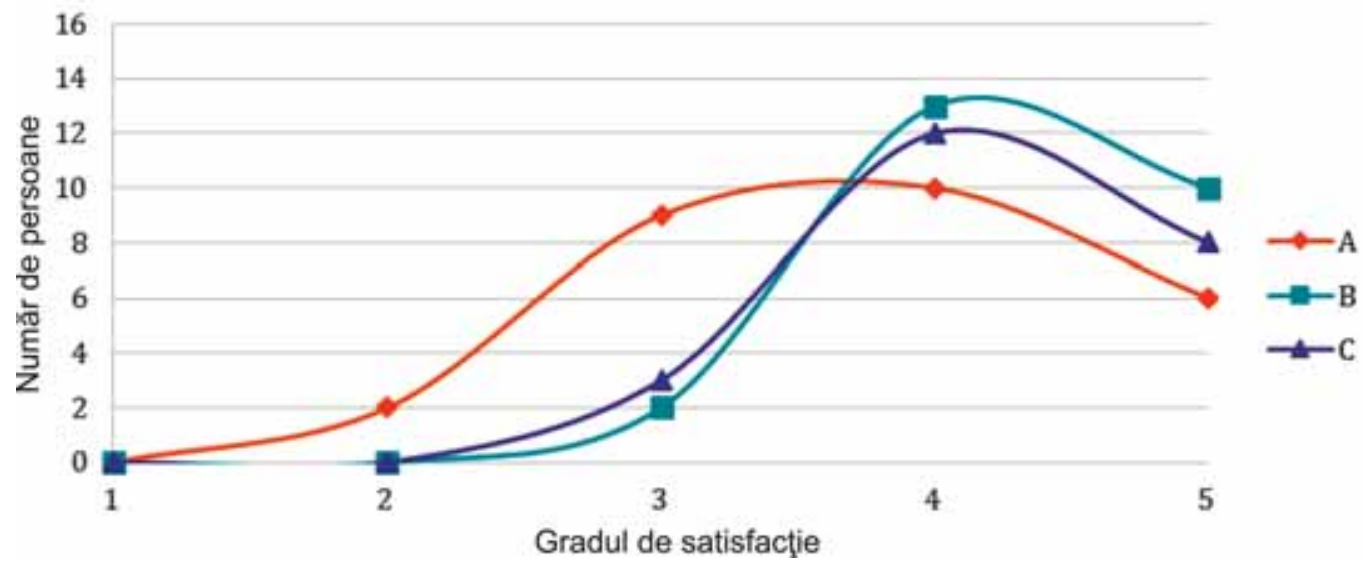


praprotezări sunt mai mulțumiți, răspunzând mai mult cu bine şi excelent. Între cele două tipuri de supraprotezări, diferențele sunt nesemnificative, fiind imposibilă o departajare cu privire la aspectul estetic al tratamentului, ambele confirmând succesul terapeutic din clinica de Protetică. Analiza răspunsurilor s-a continuat în funcție de categoria de vârstă şi de sexul pacientului. În tabelul 6 se prezintă distribuția răspunsurilor în funcție de aceste criterii. Din punct de vedere al sexelor, la categoria de vârstă 50-65 ani, diferența statistică între femei şi bărbați este nesemnificativă. În schimb, la categoria superioară de vârstă, se observă un grad crescut de satisfacție în rândul femeilor. De asemenea, se observă că pacienții din categoria +65 ani prezintă un grad mai scăzut de satisfacție față de pacienții mai tineri.

\section{TABELUL 6}

\begin{tabular}{|l|c|c|c|c|c|c|}
\hline Nota & 1 & 2 & 3 & 4 & 5 & Scor \\
\hline $50-65 \mathrm{M}$ & 0 & 0 & 3 & 9 & 7 & 4,21 \\
\hline $50-65 \mathrm{~F}$ & 0 & 0 & 3 & 8 & 6 & 4,18 \\
\hline $65+\mathrm{M}$ & 0 & 2 & 5 & 8 & 5 & 3,80 \\
\hline $65+\mathrm{F}$ & 0 & 0 & 3 & 10 & 6 & 4,16 \\
\hline
\end{tabular}

Referitor la masticaţie, putem observa în graficul de la Fig. 2 o departajare destul de semnificativă între protezarea convențională şi celelalte două tipuri de protezări. Unii pacienți protezaţi convenţional sunt complet nesatisfăcuți sau neutri, însă marea majoritate au preferat să aprecieze cu „moderat" calitatea actului masticator. Celelalte două supraprotezări sunt net superioare la acest capitol, cei mai mulți pacienți evaluându-le cu bine şi cu excelent. Balanța satisfacției înclină uşor în favoarea pacienților cu supraproteze pe dinți naturali. Ne şi aşteptam la acest aspect, datorită structurilor dinte-sistem parodontal, ce pot oferi pacienților senzație proprioceptivă şi mai multă încredere şi siguranță în timul masticației, rezultate coroborate şi cu literatura de specialitate (14).

Analizând pe sexe (Tabelul 7), la categoria de vârstă 50-65 ani, bărbații sunt uşor mai satisfăcuţi decât femeile de aceeaşi vârstă. În schimb, la pacienții de peste 65 de ani, gradul de satisfacție al bărbaților scade considerabil în detrimentul femeilor, care se arată mai mulțumite. Comparând doar grupele de vârstă, observăm din nou un grad crescut de satisfacție la pacienții mai tineri.

\section{TABELUL 7}

\begin{tabular}{|l|l|l|l|l|l|l|}
\hline Nota & 1 & 2 & 3 & 4 & 5 & Scor \\
\hline $50-65 \mathrm{M}$ & 0 & 1 & 4 & 8 & 6 & 4,00 \\
\hline $50-65 \mathrm{~F}$ & 0 & 1 & 4 & 8 & 5 & 3,94 \\
\hline $65+\mathrm{M}$ & 1 & 2 & 6 & 7 & 4 & 3,55 \\
\hline $65+\mathrm{F}$ & 1 & 1 & 4 & 8 & 4 & 3,72 \\
\hline
\end{tabular}

La capitolul fonație, putem observa în Fig. 3 o impunere a supraprotezării pe miniimplanturi. Majoritatea pacienților purtători de implanturi au ales ca răspuns bine şi excelent, fiind foarte mulțumiţi de restaurarea funcției fonatorii. Pacienții cu supraproteze pe dinți au un grad de satisfacție inferior celor cu miniimplanturi, majoritatea alegând să aprecieze cu moderat calitatea exprimării în urma tratamentului. Cele mai mari nemulțumiri le-am întâlnit la pacienții protezați convențional. Unii pacienții au afirmat că au întâmpinat aceste dificultăţi încă de la început, din cauza neadaptării la noile condiții, iar alții, după o perioadă, în urma resorbțiilor osoase apărute. Aceste rezultate au confirmat aşteptările noastre, dar şi rezultatele altor studii

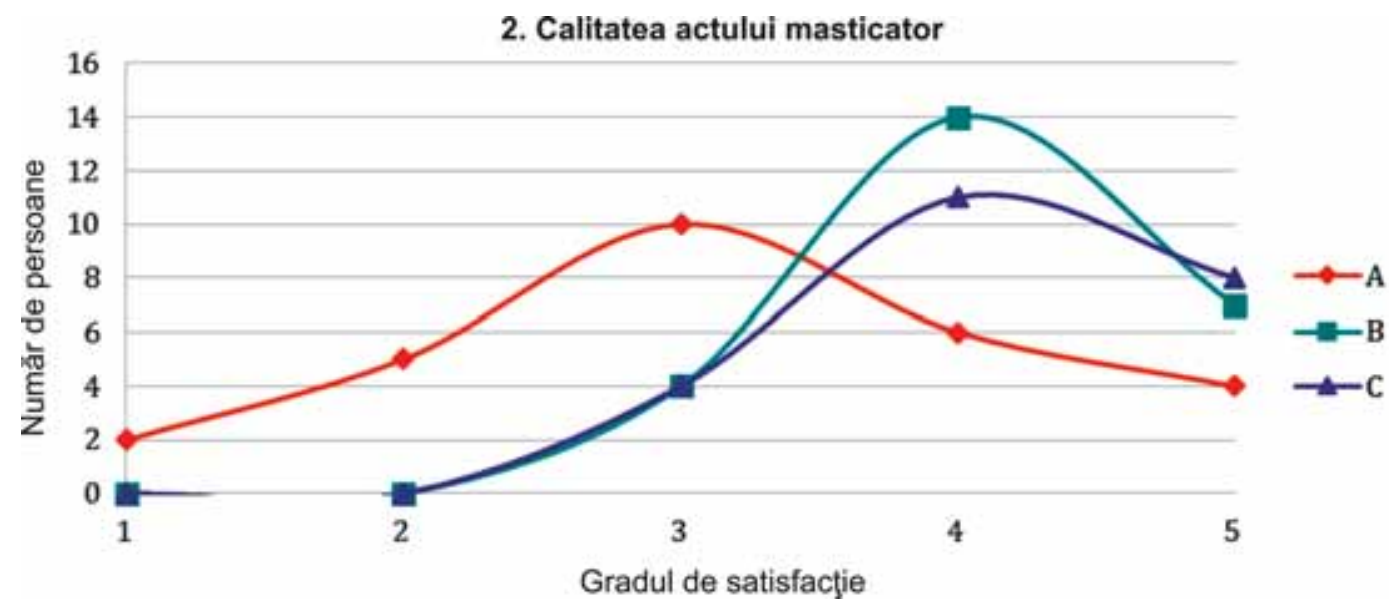




\section{Calitatea vorbirii}

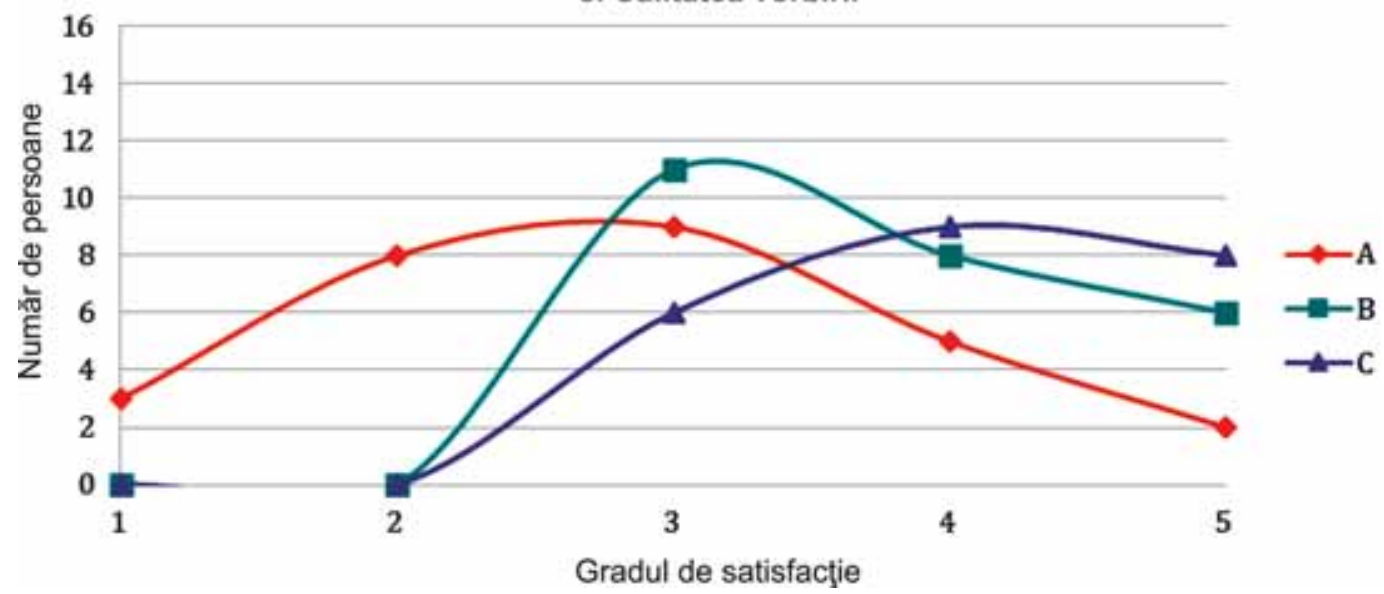

FIGURA 3

care prezintă dificultățile de exprimare ale pacienților cu proteze totale clasice. Comparând pacienții în funcție de sex, femeile sunt mai satisfăcute decât bărbații când vine vorba de restaurarea fonației. Analizând grupele de vârstă, observăm acelaşi grad crescut de satisfacție la pacienții mai tineri (Tabelul 8).

TABELUL 8

\begin{tabular}{|l|l|l|l|l|l|l|}
\hline Nota & 1 & 2 & 3 & 4 & 5 & Scor \\
\hline $50-65 \mathrm{M}$ & 1 & 1 & 7 & 5 & 5 & 3,63 \\
\hline $50-65 \mathrm{~F}$ & 0 & 2 & 6 & 5 & 4 & 3,65 \\
\hline $65+\mathrm{M}$ & 1 & 3 & 7 & 6 & 3 & 3,35 \\
\hline $65+\mathrm{F}$ & 1 & 2 & 6 & 6 & 4 & 3,53 \\
\hline
\end{tabular}

În Fig. 4 se observă traseul comun al celor trei tipuri de protezare cu privință la uşurința cu care pacienții reuşesc sa realizeze o igienizare corespunzătoare. Am putea spune chiar că cele mai multe răspunsuri excelent le-am primit de la pacienții protezați convențional. Spre deosebire de pacienții cu supraprotezări, avantajul lor este că nu prezintă sisteme speciale la nivelul cavității orale, iar lucrările protetice nu prezintă retenții sau locaşuri speciale. $\mathrm{Cu}$ toate acestea, şi pacienţii supraprotezaţi pe dinţi sau miniimplanturi, în urma instrucțiunilor şi a ale exemplificărilor, nu s-au plâns de dificultăţi în igienizarea lucrărilor protetice şi a cavității orale.

\section{TABELUL 9}

\begin{tabular}{|l|l|l|l|l|l|l|}
\hline Nota & 1 & 2 & 3 & 4 & 5 & Scor \\
\hline $50-65 \mathrm{M}$ & 0 & 0 & 5 & 7 & 7 & 4,11 \\
\hline $50-65 \mathrm{~F}$ & 0 & 1 & 5 & 7 & 4 & 3,82 \\
\hline $65+\mathrm{M}$ & 0 & 1 & 6 & 7 & 6 & 3,90 \\
\hline $65+\mathrm{F}$ & 0 & 1 & 6 & 8 & 4 & 3,79 \\
\hline
\end{tabular}

Analizând rezultatele în funcție de sex şi vârstă, bărbații din ambele categorii de vârstă percep realizarea igienizării cu mai puține dificultăți comparativ cu femeile (Tabelul 9). Această diferență statistică nu a avut ca echivalent un status oral nefavorabil în rândul femeilor incluse în studiu. În urma examinării clinice a eşantionului, nu s-a constatat că bărbații au avut o igienă orală mai satisfă-

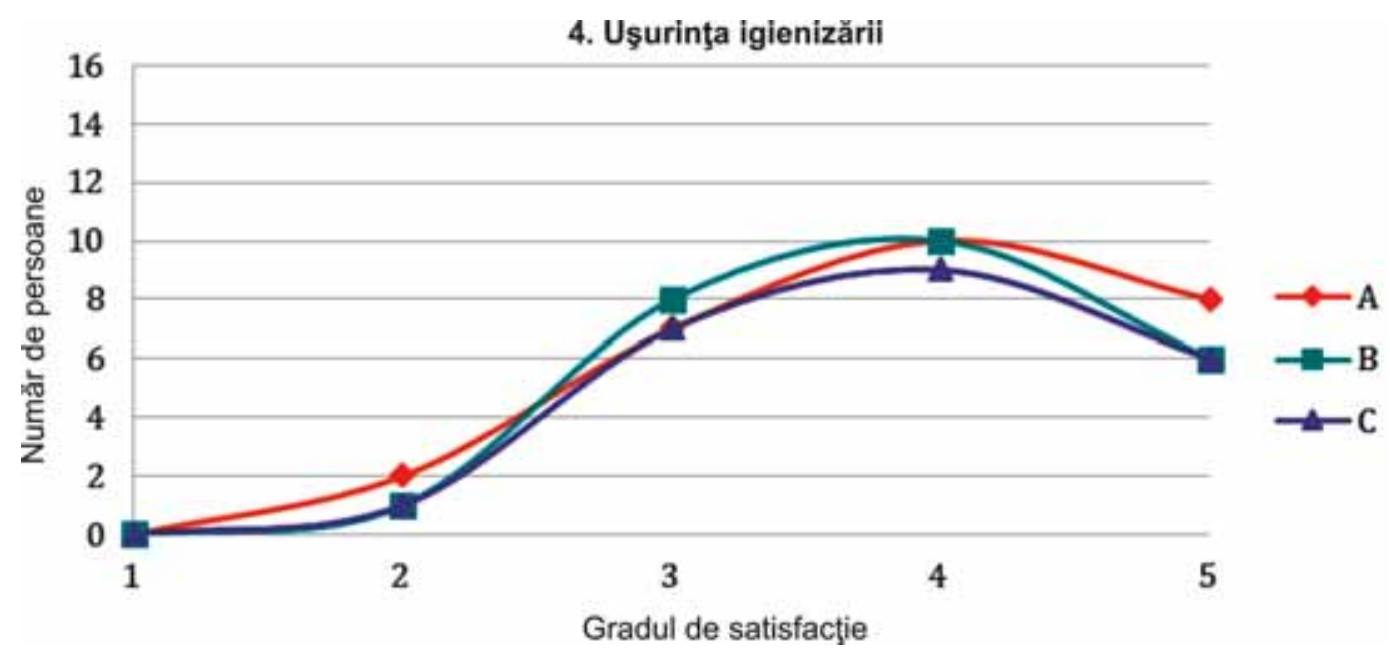




\section{Uşurinţa aplicării şi dezinserţiei}

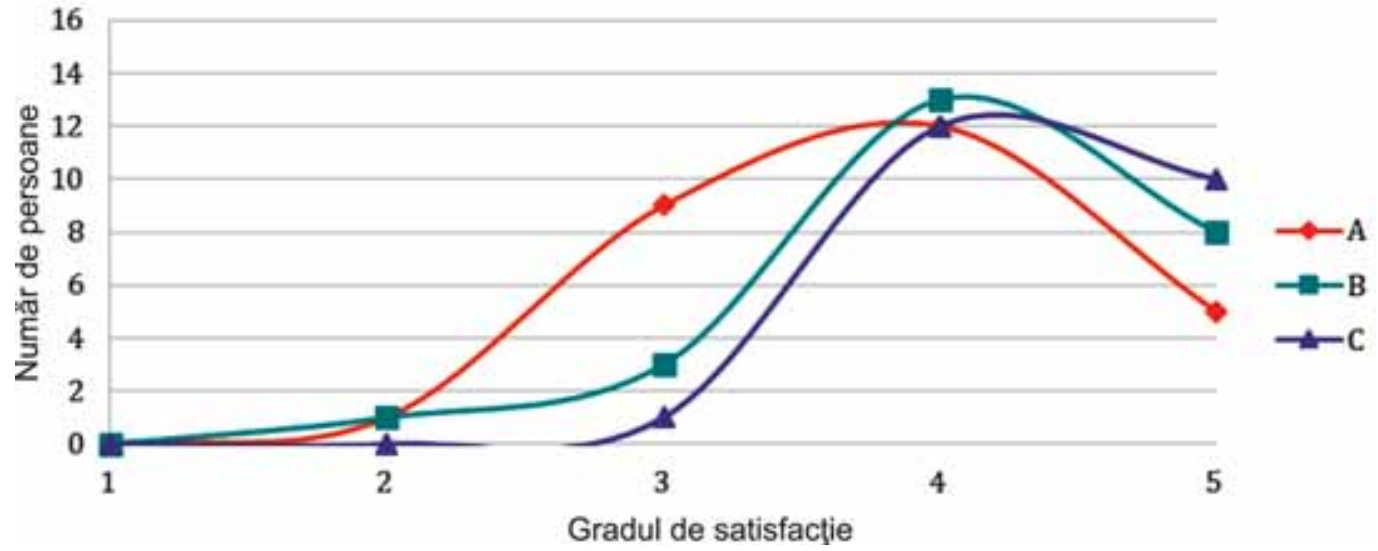

FIGURA 5

cătoare, ba chiar am sesizat o îngrijire mai bună în rândul femeilor. Aşadar, putem trage concluzia că această apreciere a bărbaților privind uşurința igienizării provine din neglijarea acestui aspect sau acordarea unei atenții scăzute. În acelaşi timp, cu cât pacienții înaintează în vârstă, cu atât igienizarea devine mai dificilă.

Comparația referitoare la modul de aplicare şi dezinserție a lucrărilor protetice (Fig. 5) ne arată un grad crescut de uşurință în grupul pacienților cu supraproteze pe miniimplanturi. Diferența nu este mare, însă aplicarea miniimplanturilor în număr adecvat şi în locul potrivit, alături de lipsa erorilor de confecționare a lucrărilor protetice şi de montare a sistemelor speciale, confirmă că această soluție de tratament va aduce cel mai mare grad de satisfacție şi confort (15). Nici celelalte tipuri de protezare nu au înregistrat rezultate slabe, majoritatea pacienților neîntâmpinând probleme la acest capitol. Pe locul doi ca grad de uşurință se află grupul pacienților cu supraproteze pe dinți, urmați de paci- enții cu proteze convenționale. Analizând în funcție de sex, bărbații cu vârsta între 50 şi 65 de ani sunt uşor mai satisfăcuți decât femeile cu privire la acest aspect. Lucrurile se schimbă însă la pacienții mai în vârstă, raportul inversându-se în detrimentul femeilor. Aşa cum ne-am aşteptat, gradul de satisfacție este mai scăzut la pacienții de peste 65 de ani, fiind din ce în ce mai dificile aplicarea şi dezinserţia protezelor odată cu înaintarea în vârstă (Tabelul 10)

\section{TABELUL 10}

\begin{tabular}{|l|c|c|c|c|c|c|}
\hline Nota & 1 & 2 & 3 & 4 & 5 & Scor \\
\hline $50-65 \mathrm{M}$ & 0 & 0 & 3 & 9 & 7 & 4,21 \\
\hline $50-65 \mathrm{~F}$ & 0 & 0 & 3 & 9 & 6 & 4,17 \\
\hline $65+\mathrm{M}$ & 0 & 1 & 4 & 10 & 5 & 3,95 \\
\hline $65+\mathrm{F}$ & 0 & 1 & 3 & 9 & 5 & 4,00 \\
\hline
\end{tabular}

Succesul în timp a unui tratament este confirmat şi de numărul cât mai scăzut de vizite pentru probleme legate de disconfort sau de fractura protezei

\section{DISTRIBUTIA INTERVENTIILOR MEDICALE}

$$
\text { m }>4 \text { = } 3=2 \text { = } 1 \text { =0 }
$$

C

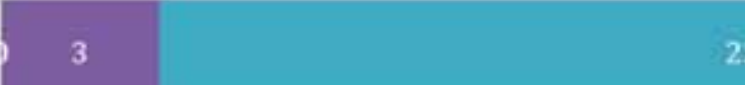

B

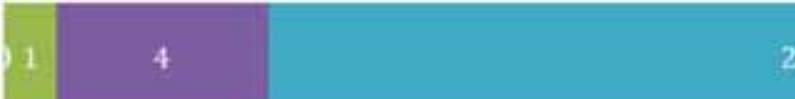

22

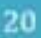


sau a unor componente. Din fericire, aşa cum se observă în Fig. 6, toate cele trei tipuri de protezări se situează foarte bine, majoritatea pacienților bucurându-se de lipsa oricăror probleme. Au existat câteva cazuri în care pacienții au solicitat una sau două vizite la clinică pentru probleme minore, dar, din punct de vedere statistic, nu putem face o diferențiere evidentă sau o departajare între cele trei categorii. Cu toate acestea, cele mai multe solicitări le-am primit din partea pacienților cu supraproteze pe dinți, probabil pentru că aceştia tind să folosească forțe masticatorii crescute datorită păstrării feedback-ului senzorial şi a sprijinului şi stabilităţii crescute a acestor restaurări. Astfel, supraprotezele sunt mai susceptibile la fractură decât protezele totale şi de aceea trebuie confecționate corespunzător, necesitând armarea bazei protezei sau mezostructura metalică pentru a rezista în timp (16).

\section{CONCLUZII}

În privința refacerii funcționalității ADM, refacerea funcției masticatorii este net superioară în ambele categorii de supraprotezări comparativ cu protezarea totală convențională, eficiența cea mai mare revenind pacienților $\mathrm{cu}$ supraprotezare pe dinţi naturali, datorată păstrării sensibilității proprioceptive. Referitor la reabilitarea estetică, gradul de satisfacție cel mai ridicat este oferit de supraprotezările pe dinţi naturali şi pe miniimplanturi, prin păstrarea contururilor faciale armonioase, datorată ratei reduse a resorbției osoase. Restaurarea funcției fonetice a adus un grad crescut de satisfacție pacienților cu supraprotezări comparativ cu cei protezați convențional, cu un grad ridicat de confort în timpul conversaţiei şi o stare de bine în pri- vința activităților sociale. Referitor la uşurința cu care se realizează igienizarea, nu s-a observat o diferență statistică între cele 3 tipuri de protezări.

Uşurinţa inserării şi dezinserării protezelor a înregistrat rezultate bune la toate categoriile de pacienți. Pacienții cu miniimplanturi au fost cei mai satisfăcuți, însă diferențele au fost foarte mici.

Din punctul de vedere al vizitelor la clinică pentru probleme legate de disconfort sau de fractura protezei sau a unor componente, cele mai multe solicitări le-am primit din partea pacienților cu supraproteze pe dinți. Diferențele au fost însă foarte mici, aşa că putem spune că toate cele trei tipuri de protezare se situează foarte bine, majoritatea pacienților bucurându-se de tratamente durabile în timp.

Astfel, referitor la semnificaţia clinică, studiul arată că, pentru a conferi satisfacție pacienților edentaţi total şi o ,uşurință“ în ceea ce priveşte adaptarea lor la condiţia de edentat total protezat, medicul stomatolog trebuie să cunoască toate alternativele de tratament, fiecare dintre ele oferind beneficii distincte. Trebuie luat în calcul, în cadrul trecerii de la stadiul de dentat la cel de edentat, alternativa supraprotezării pe dinți naturali. Medicul dentist trebuie să cunoască metodele de supraprotezare pe implanturi sau miniimplanturi, astfel încât să poată răspunde cerințelor şi exigențelor pacientului atât din punct de vedere funcțional, cât şi al succesului pe termen lung al terapiei edentației totale.

\section{Mențiune}

Toți autorii au contribuții egale la realizarea acestui articol.

Conflict of interest: none declared Financial support: none declared

\section{BIBLIOGRAFIE}

1. Hutu E. Edentaţia totală. Bucureşti, 2005, Editura Naţional.

2. Asja C., Dubravka K.-Z., Milan P., Vlado C., Ivo B., Jasmina S. Factors Related to Patient Satisfaction With Complete Denture Therapy. J. Gerontol. A Biol. Sci. Med. Sci., 2003 Vol. 58.

3. Shah F.K., Gebreel A., Elshokouki A.H., Habib A.A., Porwal A. Comparison of immediate complete denture, tooth and implant-supported overdenture on vertical dimension and muscle activity. The Journal of Advanced Prosthodontics, 2012 4: 61-71.

4. Melescanu-Imre M., Marin M., Preoteasa E., Tancu A.M., Preoteasa C.T. Two implant overdenture - the first alternative treatment for patients with complete edentulous mandible Journal of Medicine and Life, $2011 \mathrm{Vol}$ IV

5. Scotti R., Melilli D., Pizzo G. Overdenture su denti naturali, analisi dei vantaggi clinici. Minerva Stomatologica, 2003 52: 201-210.

6. Mericske-Stern R. Treament outcomes with implantsupported overdentures: clinical considerations. J. Prosthet. Dent.,1998 Vol. 79, 66-73.

7. Preiskel H. Overdentures Made Easy: A guide to implant and root supported prostheses. Chicago, 2000 Quintessence Publishing 
8. Shaktin T., Todd E. Mini-Dental Implants for General Dentist: A Novel Tehnical Approach for Smaller Diameter Implant Placement, 2002 Compendium , 119.

9. Shatkin T. Mini Dental Implants for Long Term Fixed and Removable Prosthesis: A Retrospective Analyses of 2514 Implants Placed Over Five Years Period. Compendium Contin. Educ. Dent. 2007 Vol 28 .

10. Zarb G., Albrektsson T. Osseointegration: A requiem for the periodontal ligament. Int. J. Periodont Rest Dent. $1991 \mathrm{Vol}$ 11, 88-91.

11. Morais J., Heydecke G., Pawliuk J., Lund J., Feine J. The effects of mandibular two-implant overdentures on nutrition in elderly edentulous individuals. Journal of Dental Research 2003, 82: 53-58.

12. Preoteasa E., Melescanu-Imre M., Preoteasa C.T. A 3-year Follow-up Study of Overdentures Retained by Mini-Dental
Implants .The International Journal of Oral \& Maxillofacial Implants 2014 ,Vol. 29, No.5,1170-1176.

13. Morneburg T.R., Peter A., Proschel D.R. Success rates of microimplants in edentulous patients with residual ridge resorption. Int J Oral Maxillofac Implants 2008, 270-276.

14. Mioche L., Bourdiol P., Peyron M. Influence of age on mastication: effects on eating behaiviour. Nutrition Research Reviews 2004, Vol. 17, 43-54.

15. Griffitts T.M. C.C. Mini dental implants: an adjunct for retention, stability, and comfort for the edentulous patient. Oral Surg Oral Med Oral Pathol Oral Radiol 2005, 81-84.

16. Doundoulakis James H., Eckerts Steven E., Lindquist Clarence $\mathbf{C}$. The implant supported overdenture as an alternative to the complete mandibular denture. J. Am. Dental Ass. 2003, Vol. 134, 1455-8. 